International Journal of Engineering \& Technology, $7(4)(2018) 2035-2038$
International Journal of Engineering \& Technology
SPC
Website: www.sciencepubco.com/index.php/IJET
doi: $10.14419 /$ ijet. $v 74$ it.16384
Research paper

\title{
Development of computer-based interactive multimedia : study on learning in elementary education
}

\author{
Reza Rachmadtullah ${ }^{1 *}$, Zulela MS $^{1}$, Mohamad Syarif Sumantri ${ }^{1}$ \\ ${ }^{1}$ State University of Jakarta, Indonesia \\ *Corresponding author E-mail: rezarachmadtullaheza@gmail.com
}

\begin{abstract}
Computer-based learning media is the use of a computer to help present learning materials to students, monitor the progress of learning or choose additional learning materials in accordance with student learning needs individually or is a form of application and use of computers that are applied in student learning directly to convey the content of the lesson, providing student learning exercises. The purpose of this study is the development of interactive multimedia computer-based on the subject of civic education in elementary education. This research method using an approach of research and development with stages: requirement analysis, design, and validation expert. The results of this study found that interactive multimedia applications based on computer valid and suitable for use in teaching and learning activities in primary schools.
\end{abstract}

Keywords: Interactive Multimedia; Computer-Based Learning; Elementary Education.

\section{Introduction}

Science and technology have developed rapidly from time to time, as same as the science in the media and technology. The computer uses is increasingly widespread not only in the workplace but also in education. This is because learning using computers can help speed up the development and utilization of information and communication media in education. Teachers are required to improve the quality of education and also create an effective and innovative learning atmosphere [1]. In this era, teachers are expected to have the ability to: (a) utilize the optimal learning resources in the learning process, (b) create and develop new ideas; (c) reduce the knowledge gaps that learners gain from schools with the knowledge they will gain (d) clarify the relevance and the relation in a community real life, (e) develop the knowledge, skills, and behavior of students gradually and intact, (f) provide opportunities for students to develop optimal in accordance with its ability[2]-[4].

Learning civic education in elementary school emphasizes the formation of character, morality, and understanding of politics, democracy, state system and learn about how to be a good citizen [5], [6]. To facilitate the achievement of civic education goals in Elementary school teachers should generally be able to define methods and instructional media that compatible with the material presented [3], [7]. But in fact, the media as one source of learning and has been known as a tool in the learning process that should be utilized by teachers has been overlooked. The results of interviews with teachers for reasons not using media in the learning process are generally caused by various reasons such as limited teaching preparation time, difficult to find the right media, the media price is too expensive to be afforded. To solve the problems of teachers who experience the limitations of interactive media learning then we take the initiative to develop an interesting media learning that can make students interactive so that students can learn in a fun way to form a conducive learning atmosphere.
Learning media that will be developed in this research is a computer-based interactive multimedia application where in this multimedia application has the content of learning materials, games, quiz, and development of computer-based interactive multimedia is also easily accessible by teachers using the internet networ.

\section{Literature review}

Computers are a type of media that can virtually provide an immediate response to student learning outcomes. Moreover, computers have the ability to store and manipulate information as needed. The rapid development of technology has enabled computers to load and display various forms of media in it. In this case Heinich, Molenda, \& Russell Suggests that: "... It has the ability to control and integrate a wide variety of media - still pictures, graphics, and moving images, as well as printed information. The computer can also record, analyze, and react to student responses that are typed on a keyboard or selected with a mouse ".[8]

Currently, computer technology is no longer only used as a means of computing and word processing (word processor) but also as a multi-media learning tool that allows learners to create design and engineering of a concept and science. A computer-based multimedia presentation can be interpreted as a technology that optimizes the role of the computer as a means to display and engineering text, graphics, and sound in an integrated view. With a view that combines the various elements of information and messaging, computers can be designed and used as an effective technology medium for learning and teaching relevant learning materials such as graphic design and animation [9]

The learning process that takes place in the development of science and technology of computer role is used frequently, whether it is learning in the classroom or independent learning outside of school. The process of developing learning interactive multimedia, will more often use the computer as the main media, in addition to other tools. According to Munir [10] interactive multimedia is a 
multimedia display designed by the designer so that the appearance of fulfilling the function of informing the message and have interactivity to the user. The function of multimedia is mostly to learn media, games, movies, medical, business, sports, advertising or promotion, and others. Multimedia is a combination of text, art, sound, animation, and video delivered to you via computer or electronic or other digital [11]-[13]. The development process in computer-based multimedia learning can be seen in the picture below:

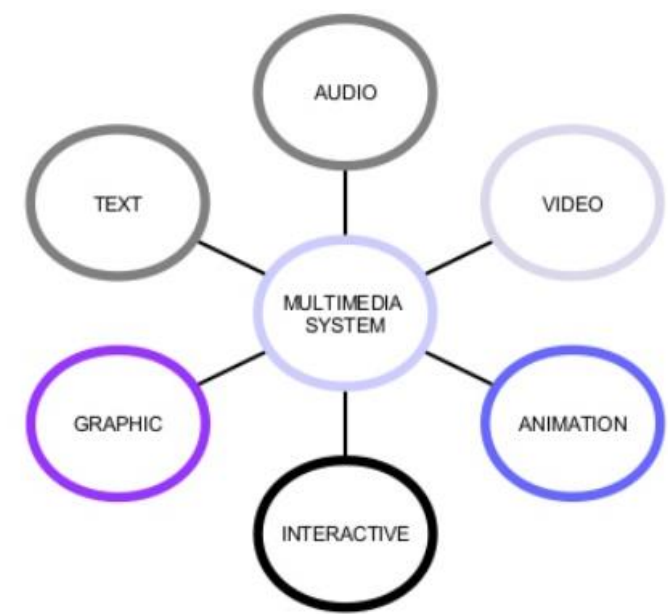

Fig. 1: The Developing Process in Learning Multimedia Based on Computer.

Multimedia is divided into two categories (a) Linear Multimedia and (b) Interactive Multimedia. A linear multimedia is a multimedia that is not equipped with any controller that the user can operate. This multimedia runs sequentially. Examples: TV and movies. Interactive multimedia is a multimedia equipped with useroperated controller tools, so they can choose what they want for the next process.

Examples of interactive multimedia are interactive games and CD applications. The description in advance describes an important concept, that is, if the user gets the flexibility in controlling the multimedia, then the device is categorized as an interactive multimedia. The most important characteristic of interactive media is the students not only pay attention to the media or object but also required to interact during learning [14]

Interactive multimedia is an appropriate alternative learning medium for classroom learning situations with learning strategies designed and developed to facilitate and enhance student interest in learning [15], [16]. [17] States that the interactive multimedia function can explain complex and dynamic concepts more clearly, facilitate to remember content easily and improve understanding of topic content through student perspective and make students more interested in learning. Teaching and learning are what we are going to do, foster deeper learning in students. First, multimedia instruction messages can be designed to serve as tools to human learning [18]-[22]. Second, there is a growing research base that learns more from multimedia verbal-only messages, including improved performance on the tests of problem-solving transfers [22]-[25].

Learning using Interactive Multimedia has its advantages, according to the Nusir [26] learning using Interactive multimedia, offering an effective dialogue between teachers and students compared to traditional teaching methods that may not have such interactivity. Jyotsna [27]in his research suggests learning using interactive multimedia results in higher academic achievement (and more pedagogically effective). This is because interactive multimedia provides the ease for students to use it and the interest of multimedia display makes this media become more superior.

\section{Methodology}

This research uses research and development method. The main purpose of this study is to produce learning tools on the subject of civic education in the form of interactive multimedia applications that are expected to have a validation and a good level of effectiveness. The stages of research conducted: (1) needs analysis that is by collecting various information related to the learning media in the civic education. (2) design and development (3) Validate the feasibility of computer-based interactive multimedia

The data collection instruments used in this development research are; (1) a material validation sheet containing an indicator of material conformity with the basic competencies used; (2) a multimedia validation sheet containing indicators on the technical aspects of the media programming as well as the design shown; (3) practitioner field validation sheets containing indicators covering aspects of legibility, interactivity and suitability of multimedia development materials; (4) The student response questionnaire contains indicators on ease of use, readability, material content and media appeal as a means or learning tool of related material.

The technique of data analysis in this research that the data obtained is analyzed, described and inferred based on qualification criterion of media learning validity, to determine the validity criterion which multimedia product developed. Criteria validity of learning media is valid if the average score is 4.00 .

\section{Results}

From the research and development that has been done, the results obtained at each stage in accordance with research and development procedures described as follows:

\subsection{Needs analysis}

Based on field survey, the result of requirement analysis at the time of civic education activity in elementary school, west Borneo Indonesia as follows: students feel bored and less interesting to learn using picture and textbook media so that new innovation in learning process in class; interview results found that some teachers experience problems in developing interactive learning media because teachers have limitations on software to create media. This makes us initiative to conduct research and development of interactive multimedia based computer that teachers in the west Borneo region of Indonesia can use.

The interactive multimedia that we develop use an easy language to understand by learners and provide illustrations or images commonly seen in daily. Development of navigation in multimedia is expected to provide simple links to make it easier for students to see the material they want and is responsive to the commands or operations performed by learners, Multimedia Packaging is made by emphasizing on the interactive aspect, not boring, using the language that is easy to understand, and provide intelligent solutions in solving a problem contained in the material, multimedia display is expected to appear in the form of much in demand and liked by students, as well as relating to the desired experience of students, multimedia is expected to provide a learning experience becomes easier in understanding a material.

\subsection{Design and development}

Product Development resulting from research and development is an interactive multimedia that is packaged in one file (Compact Disk) in summary. The resulting interactive multimedia contains images, videos, animations, text, and narration about the material. On learning civic education. Interactive multimedia product specification in the form of an opening page or interactive multimedia title is a page that displays interactive multimedia titles, media constituent identity, an advisor or mentor of multimedia compilation. The home page displays six main menus in interactive multimedia that is competence menus, materials, evaluations, devel- 
opers, and references and helps buttons, voice buttons (to turn off or turn on audio in interactive multimedia). Here is an example of a computer-based interactive multimedia application on civic educatin lessons in elementary school:

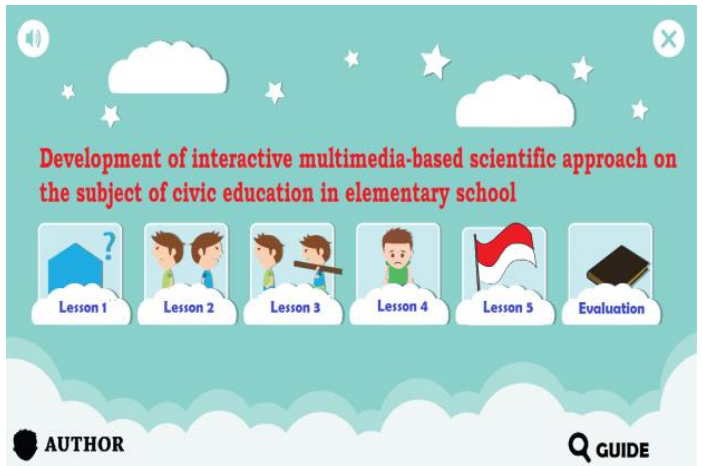

Fig. 2: Show the Main Menu of Computer-Based interactive Multimedia.

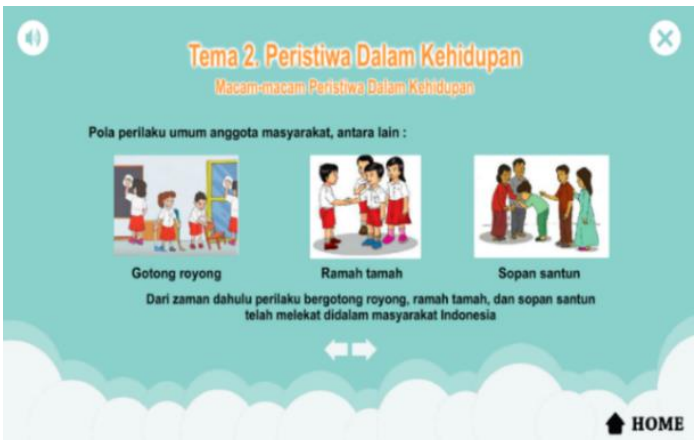

Fig. 3: Displays Learning Materials about the Importance of Living in Harmony.

\subsection{Expert validation results}

Media validation results were calculated and analyzed using data analysis techniques and obtained conclusions as listed in the Table below;

Table 1: Recapitulation of Interactive Multimedia Experts

\begin{tabular}{lllll}
\hline Aspect & Indicator & $\begin{array}{l}\text { Preferred } \\
\text { Item }\end{array}$ & Value & Average \\
\hline & $\begin{array}{l}\text { Display Design } \\
\text { Text / Typography }\end{array}$ & 3 & 15 & 5 \\
& $\begin{array}{l}\text { Image on Multi- } \\
\text { media }\end{array}$ & 4 & 10 & 5 \\
$\begin{array}{l}\text { Interactive } \\
\text { multimedia } \\
\text { view }\end{array}$ & $\begin{array}{l}\text { Animation on } \\
\text { multimedia }\end{array}$ & 2 & 19 & 4.75 \\
& $\begin{array}{l}\text { Audio } \\
\text { Multimedia pack- }\end{array}$ & 2 & 9 & 4.5 \\
$\begin{array}{l}\text { Programming } \\
\text { of interactive } \\
\text { multimedia } \\
\begin{array}{l}\text { applications } \\
\text { Amount }\end{array}\end{array}$ & Use of multimedia & 5 & 9 & 4.5 \\
\hline
\end{tabular}

From the table, it can be seen that the multimedia validation by the media expert got the average feasibility of 4.87 which can be categorized Very Good, and as a referral can be seen as follows:

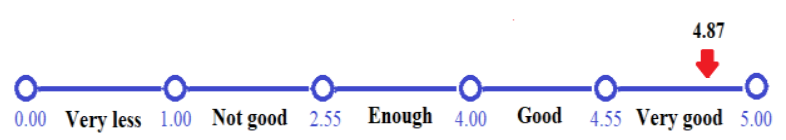

The results of validation by the material experts are presented in the following table:
Table 2: Result of Recapitulation of Civic Education Material Experts

\begin{tabular}{|c|c|c|c|c|}
\hline Aspects of & Indicator & $\begin{array}{l}\text { Item } \\
\text { Problem }\end{array}$ & Rating & Average \\
\hline \multirow{6}{*}{$\begin{array}{l}\text { Eligibility } \\
\text { for material } \\
\text { content of }\end{array}$} & $\begin{array}{l}\text { Conformity de- } \\
\text { scription of the } \\
\text { material with Basic } \\
\text { Competencies and } \\
\text { Indicators }\end{array}$ & 2 & 9 & 4.5 \\
\hline & $\begin{array}{l}\text { The accuracy of the } \\
\text { material }\end{array}$ & 2 & 10 & 5 \\
\hline & $\begin{array}{l}\text { Creative learning } \\
\text { support }\end{array}$ & 4 & 19 & 4.75 \\
\hline & $\begin{array}{l}\text { Mechanical presen- } \\
\text { tation }\end{array}$ & 2 & 10 & 5 \\
\hline & $\begin{array}{l}\text { presentation of } \\
\text { learning }\end{array}$ & 2 & 10 & 5 \\
\hline & $\begin{array}{l}\text { completeness of the } \\
\text { presentation of the } \\
\text { material }\end{array}$ & 5 & 24 & 4.8 \\
\hline \multirow[t]{3}{*}{$\begin{array}{l}\text { Feasibility } \\
\text { of material } \\
\text { presentation }\end{array}$} & $\begin{array}{l}\text { Suitability of the } \\
\text { material with the } \\
\text { characteristics of } \\
\text { students }\end{array}$ & 1 & 5 & 5 \\
\hline & $\begin{array}{l}\text { attractiveness of } \\
\text { the presentation of } \\
\text { the material }\end{array}$ & 1 & 4 & 5 \\
\hline & $\begin{array}{l}\text { Conformity exer- } \\
\text { cises with indicator }\end{array}$ & 1 & 4 & 4 \\
\hline Total & & 20 & 95 & 4.75 \\
\hline
\end{tabular}

The table above shows the results of multimedia validation by the material experts, which has an average of 4.75 eligibility which can be categorized as Very Good, and as a referral can be summarized as follows:

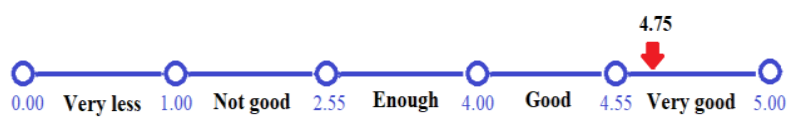

Validation by users is done to find out user ratings about the level of utilization of computer-based interactive multimedia on civic education learning at elementary school before the resulting product is implemented in the field. Obtained data as follows:

Table 3: User Validation Results

\begin{tabular}{|c|c|c|c|c|}
\hline Aspect & Participants & Score & $\begin{array}{l}\text { Number of } \\
\text { Items }\end{array}$ & Average \\
\hline Ease of use & 25 & 329 & 75 & 4.38 \\
\hline View & 25 & 786 & 175 & 4.49 \\
\hline $\begin{array}{l}\text { Quality of material } \\
\text { content }\end{array}$ & 25 & 1174 & 250 & 4.61 \\
\hline Amount & & 2289 & 500 & 4.57 \\
\hline
\end{tabular}

Bes the average percentage of multimedia users by 4.57 which can be categorized well, which means that the developed interactive multimedia is easy to use and operated by the user, so it can be implemented in further research, to measure the effectiveness of its use.

\section{Discussion}

This research produces a product of computer-based learning application that is interactive multimedia. The result of expert validation is known that the application of interactive multimediabased computer gets a worthy predicate to be used. This is also supported by the results of research which suggests that in learning, the role of multimedia computer-based become increasingly important in the present, because a multimedia system consisting of components media (text, images, graphics, animation, audio and video) are designed to complement each other so into a powerful system and appropriate, a unity of being better than the sum of its parts. Use of multimedia-based computers are acceptable in a learning on the basis of enhancing the learning process independent and active role of students. A computer-based multimedia 
system as well provide stimuli for the learning process which takes place outside the room class. [28], [29]. [22].

\section{Conclusions}

The conclusion of this research and development is the result of interactive multimedia based computer on civic education in elementary education which has been expressed its validity through validation test of multimedia expert, validation test of civic education material and product test to the user.

\section{Acknowledgements}

The authors would like to thank all those who have contributed participation in this study.

\section{Contribution Author}

Reza Rachmadtullah as correspondence author has a role as conceptualization, writing an original script, formal analysis, funding acquisition, developing instrument, methodology and looking for a reference source. While Zulela MS and Mohamad Syarif Sumantri served as supervision, data curation, instrument validation, preparing the state of the literature, All authors reflect the results and discussion.

\section{References}

[1] A. Sugari, "Development of Learning media Using Interactive Multimedia on Electronic Skills Subjects in Sagolah recognize first country 1 Mantup Lamongan," J. Pendidik. Tek. Elektro, vol. 3, no. 1, pp. 261-266, 2014.

[2] B. Zaman", Media dan Sumber Belajar [Media and Learning Resources]. Jakarta: Universitas Terbuka, 2014.

[3] M. S. Sumantri, A. W. Prayuningtyas, R. Rachmadtullah, and I. Magdalena, "The Roles of Teacher-Training Programs and Student Teachers' Self-Regulation in Developing Competence in Teaching Science," Adv. Sci. Lett., vol. 24, no. 10, pp. 7077-7081, Oct. 2018. https://doi.org/10.1166/asl.2018.12412.

[4] R. Rachmadtullah, "Kemampuan Berpikir Kritis dan Konsep Diri dengan Hasil Belajar Pendidikan Kewarganegaraan Siswa Kelas V Sekolah Dasar," J. Pendidik. Dasar, vol. 6, no. 2, p. 287, Dec. 2015 https://doi.org/10.21009/JPD.062.10.

[5] J. Cogan and R. Derricott, Citizenship for the 21st century: An in ternational perspective on education. London: Kogan Page, 2000.

[6] S. Gessner, "Teaching civic education in a migrating global community: How can students with a migration background contribute to didactics and civic education theory?," J. Soc. Sci. Educ., vol. 16 , no. 2, pp. 41-51, 2017.

[7] A. A. Candra and M. S. Masruri, "Pengembangan Multimedia Interaktif dengan Pendekatan Saintifik untuk Pembelajaran PKn SMP," Harmon. Sos. J. Pendidik. IPS, vol. 2, no. 2, pp. 109-114 2015 .

[8] R. Heinich, M. Molenda, and J. Russel, Computers are a type of media that can virtually provide an immediate response to studen learning outcomes. Moreover, computers have the ability to store and manipulate information as needed. The rapid development of technology has enabled computers to l. 1996.

[9] F. M. Van der Kleij, R. C. W. Feskens, and T. J. H. M. Eggen, "Effects of Feedback in a Computer-Based Learning Environment on Students' Learning Outcomes," Rev. Educ. Res., vol. 85, no. 4, pp. 475-511, Dec. 2015. https://doi.org/10.3102/0034654314564881

[10] Munir, Multimedia Konsepdan Aplikasi dalam Pendidikan. Bandung: Alfabeta, 2012.

[11] T. Vaughan, Multimedia making it work; 8th Edition. New York: McGraw-Hill, 2011.

[12] W. W. Lee and D. L. Owens, Multimedia-based instructional de sign: computer-based training, web-based training, distance broadcast training, performance-based solutions. John Wiley \& Sons. 2004.

[13] I. Atanasov and E. Pencheva, "Model Aspects of Open Access to Multimedia Broadcast Services in the Evolved Packet System," Int. J. Digit. Multimed. Broadcast, vol. 2016, pp. 1-13, 2016. https://doi.org/10.1155/2016/3154801.
[14] W. Wiana, "The Effectiveness of Using Interactive Multimedia in Improving the Concept of Fashion Design and Its Application in The Making of Digital Fashion Design," in IOP Conference Series: Materials Science and Engineering, 2018, vol. 306, p. 012131. https://doi.org/10.1088/1757-899X/306/1/012131.

[15] K. Chachil, R. M. Rias, A. Engkamat, A. Sarkawi, and A. R. A. Shuib, "Interactive Multimedia-based Mobile Application for Learning Iban Language (I-MMAPS for Learning Iban Language),' Procedia - Soc. Behav. Sci., vol. 75, no. 3, pp. 267-273, 2015. https://doi.org/10.1016/j.sbspro.2014.12.673.

[16] F. M. A. Khan and M. Masood, "The Effectiveness of an Interactive Multimedia Courseware with Cooperative Mastery Approach in Enhancing Higher Order Thinking Skills in Learning Cellular Respiration," Procedia - Soc. Behav. Sci., vol. 176, pp. 977-984, 2015. https://doi.org/10.1016/j.sbspro.2015.01.567.

[17] I. Hwang, M. Tam, S. L. Lam, and P. Laml, "Review of Use of Animation as a Supplementary Learning Material of Physiology Content in Four Academic Years," Electron. J. e-Learning, vol. 10, no. 4, pp. 368-377, 2012.

[18] R. E. Mayer, "Incorporating motivation into multimedia learning," Learn. Instr., vol. 29, pp. 171-173, Feb. 2014 https://doi.org/10.1016/j.learninstruc.2013.04.003.

[19] R. E. Mayer, "Research-based principles for the design of instructional messages," Doc. Des., vol. 1, pp. 7-10, 1999.

[20] R. E. Mayer, "Multimedia aids to problem-solving transfer, " Int. J. Educ. Res., vol. 31, pp. 611-623, 1999. https://doi.org/10.1016/S0883-0355(99)00027-0.

[21] R. E. Mayer, "Multimedia learning: are we asking the right questions?," Educ. Psychol., vol. 31, pp. 611-623, 1997. https://doi.org/10.1207/s15326985ep3201 1.

[22] R. E. Mayer, Multimedia learning. New York: Cambridge University Press, 2001. https://doi.org/10.1017/CBO9781139164603.

[23] H. Mandl and J. R. Levin, Knowledge acquisition from text and pictures. Amsterdam: North-Holland, 1989.

[24] L. J. Najjar, "Principles of educational multimedia user interface design," Hum. Factors, vol. 40, pp. 311-323, 1998. https://doi.org/10.1518/001872098779480505.

[25] W. Schnotz and R. W. Kulhavy, Comprehension of graphics. Amsterdam: North-Holland, 1999.

[26] S. Nusir, I. Alsmadi, M. Al-kabi, and F. Sharadgah, "Studying the Impact of Using Multimedia Interactive Programs at Children Ability to Learn Basic Math Skills," Acta Didact. Napocensia, vol. 5, no. 2, pp. 17-31, 2012 .

[27] J. Dikshit, S. Garg, and S. Panda, "Pedagogic Effectiveness of Print Interactive Multimedia, and Online Resources: A Case Study of IGNOU, ” Int. J. Instr., vol. 9, no. 1, pp. 195-210, Jan. 2016.

[28] M. S. Sumantri and R. Rachmadtullah, "The effect of learning media and self regulation to elementary students' history learning outcome," Adv. Sci. Lett., vol. 22, no. 12, pp. 4104-4108, 2016. https://doi.org/10.1166/asl.2016.8140.

[29] Wahyuningtyas and Neni, "Interactive Multimedia as Autonomous Learning Resource in the South Slope of Kelud Mt. In Blitar Regency," J. Educ. Pract., vol. 7, no. 29, pp. 168-171, 2016. 